\title{
Perbedaan Kemampuan Berpikir Kritis dan Hasil Belajar Kognitif Sistem Komputer antara Model CTL dengan Model Examples Non Examples
}

\author{
Singgih Adie Kurniawan ${ }^{1}$, Syaad Patmanthara ${ }^{2}$, Dila Umnia Soraya ${ }^{3}$ \\ ${ }^{1,2}$ Program Studi Pendidikan Teknik Informatika Universitas Negeri Malang \\ E-mail: singgih.adieka@gmail.com
}

\begin{abstract}
This study aims to determine the differences in critical thinking skills and cognitive learning outcomes of computer system subjects, between the experimental class (XTKJ1) using CTL model and the control class (XTKJ4) using the examples non examples model. This research is a quasi-experimental study with a posttest only control design pattern. The average results of the final abilities of students in both classes after receiving treatment, XTKJI was 89.16 and XTKJ4 was 83.90. There is an average difference of 5.26. The results of critical thinking skills in the experimental class showed $20 \%$ very high ability, $10 \%$ high ability, $42 \%$ moderate ability, $6 \%$ low ability and $13 \%$ very low ability. As for the control class the percentage obtained is $7 \%$ having very high ability, 20\% high ability, 23\% moderate ability, 20\% low ability and 30\% very low ability. T-test results showed the value of 0.002. It can be concluded that there are significant differences in critical thinking skills and cognitive learning outcomes between the experimental class and the control class.
\end{abstract}

Keywords: contextual, examples, critical, cognitive, computer

\begin{abstract}
ABSTRAK
Penelitian ini bertujuan untuk mengetahui perbedaan kemampuan berpikir kritis dan hasil belajar kognitif mata pelajaran sistem komputer, antara kelas eksperimen (XTKJ1) menggunakan model CTL dan kelas kontrol (XTKJ4) menggunakan model examples non examples di SMKN 11 Malang. Penelitian ini merupakan penelitian kuasi eksperimen dengan pola posttest only control design. Rata-rata hasil kemampuan akhir siswa di kedua kelas setelah mendapat perlakuan yaitu, kelas TKJ 1 sebesar 89,16 dan kelas TKJ 4 sebesar 83,90 . Terdapat selisih rata-rata sebesar 5,26 antara kedua kelas. Hasil kemampuan berpikir kritis pada kelas eksperimen menunjukkan 20\% kemampuan sangat tinggi, 10\% kemampuan tinggi, $42 \%$ kemampuan sedang, 6\% kemampuan rendah dan 13\% kemampuan sangat rendah. Sedangkan untuk kelas kontrol presentase yang didapat 7\% memiliki kemampuan sangat tinggi, 20\% kemampuan tinggi, 23\% kemampuan sedang, 20\% kemampuan rendah dan 30\% kemampuan sangat rendah. Hasil uji-t juga menunjukkan nilai 0,002 (dimana nilai $0,002<0,05$ ). Maka dapat disimpulkan terdapat perbedaan signifikan kemampuan berpikir kritis dan hasil belajar kognitif antara kelas eksperimen dan kelas kontrol.
\end{abstract}

Kata kunci: kontekstual, examples, kritis, kognitif, komputer

\section{PENDAHULUAN}

Pendidikan menjadi salah satu usaha dalam meningkatkan kesejahteraan dan merupakan bagian dari pembangunan nasional. Pendidikan dapat mencetak generasi-generasi yang cerdas, berkualitas, berahlak dan berbudi pekerti luhur [1]. Kurikulum 2013 dalam proses pembelajarannya harus memenuhi beberapa kriteria, salah satunya adalah mendorong dan menginspirasi siswa berpikir kritis dalam memecahkan masalah dan mengaplikasikan materi pembelajaran [2]. Berpikir kritis merupakan proses mental untuk menganalisis informasi yang diperoleh. Informasi tersebut didapatkan melalui pengamatan, pengalaman, komunikasi, atau membaca [3]. Beberapa keterampilan tertentu mendasari konsep 
berpikir kritis, khususnya keterampilan mengamati, menyimpulkan, generalisasi, penalaran, mengevaluasi penalaran dan sejenisnya [4].

Peningkatan mutu pendidikan sangatlah penting bagi pembangunan yang berkelanjutan di segala aspek kehidupan manusia. Sistem pendidikan nasional senantiasa harus dikembangkan sesuai dengan kebutuhan dan perkembangan yang terjadi baik ditingkat lokal, nasional, maupun global [5]. Perubahan dan perbaikan yang terjadi dapat mencakup kompetensi dan kualitas tenaga pendidik, mutu pendidikan, perangkat kurikulum, sarana dan prasarana pendidikan, dan mutu manajemen pendidikan termasuk pemilihan model pembelajaran yang inovatif demi mewujudkan pembelajaran yang efektif.

Joice dan Weil menyatakan bahwa model pembelajaran adalah suatu pola dan rencana yang sudah direncanakan sedemikian rupa dan digunakan untuk menyusun kurikulum, mengatur materi pembelajaran dan memberi petunjuk kepada pengajar di kelasnya [6]. Seorang guru diharapkan dapat memiliki motivasi, kreativitas dan inovasi dalam menjalankan proses pembelajaran, terutama dalam memilih model pembelajaran yang sesuai dengan mata pelajaran dan karakteristik siswa agar pembelajaran dapat terlaksana dengan menarik dan menyenangkan bagi siswa sehingga akan tercapai hasil yang maksimal. Banyak tersedia model-model pembelajaran yang dapat dipilih oleh guru untuk diimplementasikan sebagai usaha dalam rangka melakukan pembaharuan proses pembelajaran.

Pembelajaran sebaiknya dilandasi oleh prinsip-prinsip belajar sebagai berikut: (1) Berpusat pada siswa; (2) belajar dengan melakukan;

(3) mengembangkan kreativitas siswa; (4) menciptakan kondisi menyenangkan dan menantang; (5) mengembangkan beragam kemampuan yang bermuatan nilai; (6) menyediakan pengalaman belajar yang beragam; dan (7) menumbuh kembangkan kesadaran sebagai warga negara [1]. Upaya implementasi prinsip-prinsip pembelajaran tersebut bisa dikembangkan berbagai strategi dan pendekatan pembelajaran, antara lain: (1) Pendekatan pembelajaran kontekstual; (2) pembelajaran life skill; (3) Pembelajaran berbasis lingkungan dan lain-lain. Tetapi, hasil observasi di SMKN 11 Malang, guru masih menggunakan model konvensional berupa metode ceramah dalam mengajar khususnya pada mata pelajaran Sistem Komputer. Akibatnya siswa cenderung pasif di dalam kelas karena mereka merasa bosan dengan proses pembelajaran yang sedang terjadi karena hanya berpusat pada guru. Guru sebagai sumber pengetahuan dan siswa hanya bersikap pasif dalam menerima pelajaran, masih sering terjadi di dalam sistem pembelajaran di sekolahsekolah pada umumnya [7].

Pasifnya siswa dapat berimbas kurang baik terhadap kemampuan berpikir kritis yang nantinya juga akan berimbas terhadap hasil belajar kognitif siswa, terhadap materi pelajaran yang telah disampaikan pada mata pelajaran Sistem Komputer itu sendiri. Jadi seorang guru harus bisa memancing siswa agar dapat lebih aktif di dalam proses belajar dan mengajar agar dapat meningkatkan kemampuan berpikir kritis mereka. Beberapa upaya guru untuk dapat mengembangkan kemampuan berpikir siswa diantaranya adalah: (a) terlibat dalam diskusi secara aktif; (b) bertanya dan menjawab pertanyaan; (c) berpikir secara kritis; (d) menjelaskan setiap jawaban yang diberikan; dan (e) mengajukan alasan untuk 
setiap jawaban yang diajukan [8]. Hampir sebagian besar siswa kelas $\mathrm{X}$ TKJ di SMKN 11 Malang masih belum mampu untuk menggunakan konsep suatu materi yang ada dalam mata pelajaran sistem komputer yang telah diberikan oleh guru untuk mengatasi masalah yang dihadapinya dalam kehidupan sehari-hari. Siswa juga masih merasa bingung dan kesulitan dalam menyelesaikan soal yang membutuhkan kemampuan dalam menganalisis. Penguasaan keterampilan berpikir kritis dan pemecahan masalah perlu diintegrasikan dalam pembelajaran [9].

Penyebab kurangnya keterampilan berpikir kritis, salah satunya karena siswa hanya menghafal suatu konsep yang diterima langsung dari guru yang dianggap sebagai suatu kewajiban di dalam menerima pelajaran di sekolah. Keterampilan berfikir kritis merupakan salah satu keterampilan belajar yang diperlukan di abad 21 [10]. Berpikir kritis penting bagi peserta didik karena dengan berpikir kritis peserta didik dapat menganalisis dan mencari solusi serta membuat keputusan terhadap suatu masalah secara sistematis khususnya dalam pembelajaran [11]. Kemampuan menganalisis merupakan bagian dari kemampuan berpikir kritis. Sejalan dengan itu Beaton menyatakan bahwa cara berpikir kritis meliputi pemikiran analitis dengan tujuan untuk mengevaluasi apa yang telah dibaca [12]. Secara langsung kurangnya kemampuan berpikir kritis tersebut juga berdampak pada hasil belajar kognitif siswa. Perolehan rata-rata nilai dari ulangan harian siswa kelas $\mathrm{X}$ TKJ di SMKN 11 Malang terhadap mata pelajaran Sistem Komputer hampir 70\% anak masih mendapat nilai di bawah KKM yang ditetapkan yaitu 75. Artinya siswa masih banyak yang belum mencapai ketuntasan dalam belajar.

Perlu adanya penerapan model pembelajaran yang dapat membuat proses pembelajaran menjadi menarik dan menyenangkan dan juga prosesnya lebih berpusat pada siswa. Penerapan model tersebut diharapkan mampu meningkatkan motivasi siswa untuk mengikuti proses pembelajaran dengan aktif dan tujuan pembelajaran pun dapat tercapai secara optimal dengan pemahaman yang mendalam. Indikator keberhasilan belajar siswa salah satunya diukur berdasarkan daya serap terhadap bahan pengajaran yang diajarkan sehingga mencapai prestasi tinggi, baik individual maupun kelompok [13]. Keberhasilan belajar tersebut dapat diketahui melalui penilaian hasil belajar. Hasil belajar merupakan kemampuan siswa dalam memenuhi suatu tahapan pencapaian pengalaman belajar dalam satu kompetensi dasar [14].

Alternatif model pembelajaran untuk membuat suasana pembelajaran bisa menjadi lebih menarik dan menyenangkan, untuk memperkuat kemampuan berpikir kritis dan memberikan hasil maksimal terhadap kemampuan kognitif siswa yaitu Contextual Teaching and Learning (CTL) dan Examples Non Examples. Kedua model tersebut memiliki karakter yang hampir sama, dimana dalam prosesnya sama-sama mengaitkan langsung materi yang diajarkan dengan kenyataan yang ada pada kehidupan sehari-hari. Hasil belajar siswa yang menggunakan model pembelajaran kooperatif (MPK) dengan metode pembelajaran Examples Non Examples lebih tinggi secara signifikan dibandingkan dengan hasil belajar siswa yang dibelajarkan menggunakan model pembelajaran langsung (MPL) dengan metode ceramah [15]. Penerapan model 
CTL mempengaruhi hasil belajar secara positif [16].

Model CTL merupakan konsep belajar yang membantu guru mengaitkan antara materi yang diajarkan dengan situasi dunia nyata siswa dan mendorong siswa membuat hubungan antara pengetahuan yang dimilikinya dengan penerapan dalam kehidupan sehari-hari. Tujuh komponen utama yang mendasari penerapan CTL di kelas, yaitu constructivism, inquiry questioning, learning Community, modelling, reflection dan authentic assessement [17]. Examples Non Examples merupakan strategi pembelajaran yang menggunakan gambar sebagai media untuk menyampaikan materi [18]. Dengan menggunakan media gambar, siswa dapat lebih mudah untuk memahami dan menganalisis kosep yang telah diperolehnya dengan melihat gambar yang diberikan oleh guru dalam proses pembelajaran sehingga siswa memperoleh gambaran antara konsep yang ada pada materi pembelajaran dengan realita yang ada dalam kehidupannya. Penelitian ini bertujuan untuk membandingkan model CTL dan model Examples Non Examples.

\section{METODE}

Rancangan penelitian yang digunakan di dalam penelitian ini adalah Quasy Experimental Design. Quasy Experimental merupakan suatu penelitian yang dilakukan berdasarkan percobaan semu, dimana kelompok kontrol tidak dapat berfungsi sepenuhnya untuk mengontrol variabel-variabel luar yang mempengaruhi pelaksanaan eksperimen yang sebenarnya [19]. Pola yang digunakan yaitu posttest only control design yang melibatkan dua kelompok kelas yang ditetapkan sebagai sampel, yaitu kelas $\mathrm{X}$ TKJ 1 sebagai kelas eksperimen dan kelas
X TKJ 4 sebagai kelas kontrol. Kelas eksperimen diberi perlakuan menggunakan model pembelajaran CTL, sedangkan kelas kontrol menggunakan model Examples Non Examples. Desain perlakuan dalam penelitian ini dapat dilihat pada Tabel 1 dibawah ini.

Tabel 1 Rancangan Penelitian [19]

\begin{tabular}{llll}
\hline Kelompok & Pretest & Perlakuan & Post Test \\
\hline Eksperimen & $\mathrm{O}_{1}$ & $\mathrm{X} 1$ & $\mathrm{O}_{2}$ \\
Kontrol & $\mathrm{O}_{1}$ & $\mathrm{X} 2$ & $\mathrm{O}_{2}$
\end{tabular}

Keterangan:

$\mathrm{O}_{1}=$ Pretest pada kelompok eksperimen dan kontrol.

$\mathrm{O}_{2}=$ Postest pada kelompok eksperimen dan kontrol

$\mathrm{X} 1$ = Pemberian perlakuan pembelajaran dengan model CTL

$\mathrm{X} 2$ = Pemberian perlakuan pembelajaran dengan model Examples Non Examples.

Variabel bebas dalam penelitian ini adalah model CTL $\left(\mathrm{X}_{1}\right)$ untuk kelas eksperimen dan model Examples Non Examples $\left(\mathrm{X}_{2}\right)$ untuk kelas kontrol. Variabel terikat adalah kemampuan berpikir kritis $\left(\mathrm{Y}_{1}\right)$ dan hasil belajar siswa ranah kognitif $\left(\mathrm{Y}_{2}\right)$ siswa. Penentuan sampel penelitian menggunakan Teknik purposive sampling. Teknik purposive sampling didasarkan karena adanya tujuan dan pertimbangan tertentu [20]. Instrumen yang digunakan dalam penelitian ini yaitu instrumen perlakuan dan instrumen pengukuran. Teknik uji coba instrumen yang digunakan dalam penelitian ini meliputi uji validitas isi, uji validitas butir soal dan uji reliabilitas. Uji validitas isi meliputi RPP Model CTL dengan presentase rata-rata sebesar $87,5 \%$ dan RPP Model Examples Non Examples dengan persentase rata-rata sebesar $87,5 \%$. Hasil validasi isi materi sistem komputer dengan perolehan rata-rata sebesar $92,86 \%$, dan validasi soal posttest dengan perolehan presentase rata-rata sebesar $95 \%$. 
Soal post-test yang diuji dalam penelitian ini berbentuk uraian atau esai dengan jumlah 10 soal dimana telah diujicobakan sebelumnya pada 28 siswa dari kelas X TKJ 2 dan 28 siswa dari kelas $X$ TKJ 3 di SMKN 11 Malang. Jadi jumlah total sampel ujicoba sebanyak 56 siswa. Uji validitas butir soal dihitung dengan menggunakan rumus korelasi product moment [21]. Hasil yang diperoleh menunjukkan bahwa seluruh soal teruji valid, karena rhitung yang didapatkan pada setiap soal memiliki $r_{\text {hitung }}>0,2631$, jadi tidak perlu ada soal yang diganti maupun dibuang. Selanjutnya uji realiabilitas dengan teknik Cronbach's Alpha untuk mengetahui tingkat kepercayaan atau realibilitas soal itu sendiri. Jadi reliabilitas tes berhubungan dengan masalah ketetapan hasil tes [21]. Cronbach's Alpha merupakan sebuah ukuran keandalan yang memiliki nilai berkisar dari nol sampai satu [22]. Nilai tingkat keandalan Cronbach's Alpha minimum adalah 0,70 [23]. Hasil uji reliabilitas dengan Cronbach's Alpha memperoleh hasil 0,713. Dari hasil tersebut dapat diketahui bahwa soal posttest reliabel dan layak untuk digunakan.

Teknik analisis yang dilakukan pada penelitian ini adalah uji prasyarat analisis, uji kesamaan dua rata-rata, dan uji hipotesis. Uji prasyarat analisis menggunakan uji normalitas dan uji homogenitas. Data yang diuji adalah data kemampuan awal (hasil pretest yang diambil dari nilai UTS semester genap 2017/2018) dan data kemampuan akhir siswa (hasil posttest). Uji normalitas berguna untuk memastikan bahwa data yang diperoleh merupakan data yang terdistribusi normal di dalam sebuah populasi. Ada beberapa kriteria pengambilan keputusan berdasarkan nilai signifikansi yaitu, (1) Jika nilai probabilitas (Asymp.sig) $>0,05$ maka data terdistribusi secara normal; (2) Jika nilai probabilitas (Asymp.sig) < 0,05 maka data tidak terdistribusi secara normal [24]. Uji homogenitas bertujuan untuk memastikan bahwa data yang didapat dari hasil penelitian dalam suatu populasi sudah homogen atau belum. Data dapat dikatan homogen apabila nilai signifikansi (p) > 0,05. Uji normalitas menggunakan teknik uji Kolmogorov-Smirnov, dan uji homogenitas menggunakan teknik uji Levene's. Tahap terakhir adalah melakukan uji hipotesis menggunakan uji daya beda atau Uji-t dengan syarat sig.(2-tailed) > 0,05. Uji t digunakan untuk menguji apakah terdapat perbedaan yang signifikan pada kemampuan berpikir kritis dan hasil belajar kognitif siswa antara kelas eksperimen dan kelas kontrol. Ketiga uji tersebut menggunakan SPSS.

\section{HASIL DAN PEMBAHASAN}

Data kemampuan awal siswa disajikan pada Tabel 2, dan kemampuan akhir siswa disajikan pada Tabel 3 .

Tabel 2 Data Kemampuan Awal Siswa Sebelum Diberi Perlakuan

\begin{tabular}{llllll}
\hline Kelas & N & Nilai Terrendah & Nilai Tertinggi & Rata-rata & Jenis Penelitian \\
\hline Kelas eksperimen & 31 & 55 & 80 & 67,26 & Kognitif \\
Kelas kontrol & 30 & 58 & 75 & 67,57 & Kognitif \\
\hline
\end{tabular}

Tabel 3 Data Kemampuan Akhir Siswa

\begin{tabular}{llllll}
\hline Kelas & N & Nilai Terendah & Nilai Tertinggi & Rata-rata & Jenis Penelitian \\
\hline Kelas Eksperimen & 31 & 75 & 100 & 89,16 & Kognitif \\
Kelas Kontrol & 30 & 72 & 96 & 83,90 & Kognitif \\
\hline
\end{tabular}


Langkah awal adalah melakukan uji prasyarat analisis. Hasil uji normalitas kemampuan awal siswa dapat dilihat pada Tabel 4. Berdasarkan hasil pada Tabel 4, diketahui bahwa data kemampuan awal siswa menunjukkan nilai signifikansi sebesar 0,200. Sesuai dengan kriteria, jika nilai probabilitas (Asymp.sig) $>0,05$ maka data terdistribusi secara normal. Hasil uji normalitas kemampuan akhir siswa dapat dilihat pada Tabel 5. Melihat hasil uji normalitas pada Tabel 5, data kemampuan akhir siswa dari nilai uji posttest menunjukkan nilai signifikansi sebesar 0,200 . Itu menunjukkan bahwa nilai signifikansi yang diperoleh $(0,200)$ lebih besar dari nilai signifikansi 0,05 atau $(0,200$ $>0,05)$. Sesuai dengan kriteria, jika nilai probabilitas (Asymp.sig) > 0,05 maka data terdistribusi secara normal.

Tabel 4. Hasil Uji Normalitas Kemampuan Awal Siswa

\begin{tabular}{llll}
\hline Kelas & N & Asymp-Sig. & Keterangan \\
\hline Kelas Eksperimen & 31 & 0,200 & Terdistribusi Normal \\
Kelas Kontrol & 30 & 0,200 & Terdistribusi Normal
\end{tabular}

Tabel 5. Hasil Uji Normalitas Kemampuan Akhir Siswa

\begin{tabular}{llll}
\hline Kelas & N & Asymp-Sig & Keterangan \\
\hline Kelas Eksperimen & 31 & 0,200 & Terdistribusi Normal \\
Kelas Kontrol & 30 & 0,200 & Terdistribusi Normal \\
\hline
\end{tabular}

Hasil uji homogenitas kemampuan awal siswa yang disajikan dalam Tabel 6 . Hasil uji homogenitas kemampuan akhir siswa dapat dilihat pada Tabel 7. Tabel 6 menunjukkan hasil uji homogenitas sebesar 0,950 yang artinya data kemampuan awal siswa bersifat homogen. Karena 0,950 > 0,05 . Berdasarkan hasil pada Tabel 7 , signifikansi hasil uji homogenitas kemampuan akhir adalah 0,949, artinya data bersifat homogen, karena nilai signifikansi $(0,49)>0,05$.

Tabel 6. Hasil Uji Homogenitas Kemampuan Awal

\begin{tabular}{llll}
\hline Kelas & Sig & Leven’s & Keterangan \\
\hline Kelas & & & Data \\
Eksperimen & 0,950 & 0,004 & Homogen \\
Kelas Kontrol & & &
\end{tabular}

Tabel 7. Hasil Uji Homogenitas Kemampuan Akhir

\begin{tabular}{llll}
\hline Kelas & Sig & Leven's & Keterangan \\
\hline Kelas & & & Data \\
Eksperimen & 0,949 & 0,004 & Homogen \\
Kelas Kontrol & & &
\end{tabular}

Tabel 8 Hasil Uji-T Data Kemampuan Awal Siswa

\begin{tabular}{llll}
\hline Kelas & N & Rata-rata & $\begin{array}{l}\text { Asymp. } \\
\text { Sig(2-tailed) }\end{array}$ \\
\hline X TKJ 1 & 31 & 67,26 & 0,829 \\
X TKJ 4 & 30 & 67,57 & \\
\hline
\end{tabular}

Tabel 8 menunjukkan bahwa nilai signifikansi $(0,829)>0,05$. Hasil tersebut menunjukkan bahwa kelas eksperimen dan kelas kontrol memiliki kemampuan awal yang sama. Hal ini didukung dan dibuktikan dengan perolehan rata-rata nilai kemampuan awal siswa pada kelas eksperimen sebesar 67,26 dan perolehan rata-rata kelas kontrol sebesar 67,57, dengan selisih 0,31 . Selanjutnya dilakukan uji beda kemampuan akhir yang disajikan pada Tabel 9.

Tabel 9 Hasil Uji-T Data Kemampuan Akhir Siswa

\begin{tabular}{llll}
\hline Kelas & $\mathrm{N}$ & Rata-rata & $\begin{array}{l}\text { Sig.(2- } \\
\text { tailed) }\end{array}$ \\
\hline X TKJ 1 & 31 & 89,16 & 0,002 \\
X TKJ 4 & 30 & 83,90 & \\
\hline
\end{tabular}


Tabel 9 menunjukkan bahwa kemampuan akhir siswa memiliki nilai signifikansi 0,002 yang lebih kecil dari 0,05 $(0,002<0,05)$. Oleh karena itu, dapat disimpulkan bahwa, terdapat perbedaan yang signifikan baik pada kemampuan berpikir kritis maupun hasil belajar ranah kognitif siswa antara kelas yang diajar menggunakan model CTL dengan kelas yang diajar menggunakan model examples non examples. Belajar adalah aktivitas mental/psikis yang berlangsung dalam interaksi aktif dengan lingkungan yang menghasilkan perubahan-perubahan dalam kognitif, psikomotorik, dan afektif [25]. Maka bisa dikatakan bahwa terjadinya perubahan dan peningkatan hasil belajar kognitif mata pelajaran sistem komputer merupakan akibat dari pengaruh penerapan model CTL dan model examples non examples dalam proses pembelajaran. Dibandingkan perolehan nilai rata-rata kemampuan awal, perolehan nilai rata-rata kemampuan akhir sangat jauh berbeda, dan menunjukkan hasil rata-rata berada di atas KKM yaitu 75 .

Terdapat perbedaan nilai akhir yang cukup besar antara kedua kelas. Nilai akhir yang diperoleh kelas eksperimen adalah sebesar 89,16 dan kelas kontrol sebesar 83,9. Perbedaan hasil belajar kognitif siswa yang dilihat dari perolehan nilai uji post-test pada kedua kelas menunjukkan bahwa rata-rata nilai kognitif kelas eksperimen lebih tinggi secara signifikan. Hasil tersebut sejalan dengan hasil penelitian sebelumnya, dimana penggunaan model CTL dinilai meningkatkan hasil belajar [16], [26]. Pada penggunaan model examples non examples, dinilai terdapat peningkatan hasil belajar kognitif yang signifikan pada siswa sebelum diberikannya perlakuan dengan sesudah diberikan perlakuan menggunakan model pembelajaran Examples Non Examples. Hal tersebut sejalan dengan penelitian sebelumnya [15].

Terjadinya perbedaan yang signifikan antara kemampuan awal dan kemampuan akhir yang ada pada kelas eksperimen maupun kelas kontrol, merupakan hasil dari diterapkannya model pembelajaran yang baru dan berbeda oleh peneliti, yaitu model CTL dan model examples non examples. Dimana kedua model tersebut dinilai lebih membuat suasana pembelajaran di dalam kelas lebih menyenangkan dan tidak membosankan bagi siswa, jika dibandingkan dengan model pembelajaran sebelumnya yang diterapkan oleh guru (model konvensional dengan metode ceramah). Seperti yang telah diketahui sebelumnya, model pembelajaran CTL dan model examples non examples merupakan model pembelajaran yang tergolong model pembelajaran kooperatif, yang mana proses pembelajarannya lebih ditekankan pada siswa daripada pada guru. Guru disini fungsinya lebih sebagai fasilitator. Siswa pun menjadi lebih aktif dan bersemangat dalam menggali suatu informasi, serta lebih tanggap dan mudah ingat akan akan apa yang sedang mereka pelajari.

Kemampuan berpikir kritis merupakan kegiatan menganalisis ide atau gagasan ke arah yang lebih spesifik, membedakannya secara tajam, memilih, mengidentifikasi, mengkaji dan mengembangkannya ke arah yang lebih sempurna [27]. Untuk mengukur kemampuan berpikir kritis, yang digunakan merupakan data hasil penelitian kemampuan akhir (posttest). Dari hasil tersebut dapat diketahui perolehan terendah dan tertinggi dari kedua kelas yaitu sebesar 72 dan 100. Nilai terendah dan tertinggi tersebut digunakan untuk menghitung nilai 
mean (M) dan nilai standar deviasi (SD) yang digunakan untuk menentukan rentang nilai yang akan digunakan untuk mengukur pencapaian kemampuan berpikir kritis pada kedua kelas. Distribusi frekuensi kemampuan berpikir kritis kelas eksperimen (X TKJ 1) yang ditunjukkan dalam Tabel 10.

Tabel 10 Distibusi Frekuensi Kemampuan Berpikir Kritis Kelas Eksperimen.

\begin{tabular}{llll}
\hline Nilai & Kategori & (f) & $\%$ \\
\hline $94-100$ & Sangat Tinggi & 9 & $29 \%$ \\
$89-93$ & Tinggi & 3 & $10 \%$ \\
$85-88$ & Sedang & 13 & $42 \%$ \\
$80-84$ & Rendah & 2 & $6 \%$ \\
$72-79$ & Sangat Rendah & 4 & $13 \%$ \\
\hline Jumlah & & 31 & $100 \%$ \\
\hline
\end{tabular}

Melihat hasil distribusi frekuensi kemampuan berpikir kritis peserta didik pada kelas eksperimen di Tabel 10, diperoleh besarnya presentase kemampuan berpikir kritis yaitu sebesar $29 \%$ siswa masuk kategori sangat tinggi, 10\% siswa masuk kategori tinggi, $42 \%$ siswa masuk kategori sedang, $6 \%$ siswa masuk kategori rendah dan 13\% siswa masuk kategori sangat rendah. Hal tersebut sejalan dengan penelitian sebelumnya yang menyatakan bahwa CTL mampu meningkatkan keterampilan berpikir kritis siswa [28]. Distribusi frekuensi kemampuan berpikir kritis pada kelas kontrol dapat dilihat pada Tabel 11.

Tabel 11 Distibusi Frekuensi Kemampuan Berpikir Kritis Kelas Kontrol

\begin{tabular}{llll}
\hline Nilai & Kategori & (f) & $\%$ \\
\hline $94-100$ & Sangat Tinggi & 2 & $7 \%$ \\
$89-93$ & Tinggi & 6 & $20 \%$ \\
$85-88$ & Sedang & 7 & $23 \%$ \\
$80-84$ & Rendah & 6 & $20 \%$ \\
$0-79$ & Sangat Rendah & 9 & $30 \%$ \\
\hline Jumlah & & 30 & $100 \%$ \\
\hline
\end{tabular}

Hasil distribusi frekuensi kemampuan berpikir kritis peserta didik kelas kontrol pada Tabel 11, menunjukkan bahwa 7\% siswa masuk kategori sangat tinggi, 20\% siswa masuk kategori tinggi, $23 \%$ masuk kategori sedang, 20\% masuk kategori rendah dan 30\% masuk kategori sangat rendah. Dari hasil distribusi kedua kelas di atas, dapat diambil kesimpulan bahwa terdapat perbedaan pengaruh terhadap kemampuan berpikir kritis siswa antara kelas eksperimen yang diberi perlakuan dengan model CTL dengan kelas kontrol yang diberi perlakuan dengan model examples non examples.

Meskipun model pembelajaran yang diterapkan pada kelas eksperimen dan kelas kontrol sudah sesuai dengan kurikulum 2013, dimana sama-sama model pembelajaran kooperatif, serta keterlaksanaannya sudah berjalan dengan sangat baik, namun hal ini tidak menutup kemungkinan untuk tetap adanya perbedaan pada hasil belajar yang didapatkan. Pembelajaran kooperatif sendiri merupakan pembelajaran dimana siswa dalam prosesnya bekerja di dalam suatu kelompok-kelompok kecil yang anggotanya terdiri dari empat sampai enam orang dengan anggota yang heterogen. Sanjaya mengemukakan bahwa cooperative learning merupakan kegiatan siswa yang dilakukan secara berkelompok [29]. Pendapat lain juga dikemukakan oleh Suprijono bahwa pembelajaran kooperatif adalah konsep yang lebih luas meliputi semua jenis kerja kelompok termasuk bentuk-bentuk yang lebih dipimpin oleh guru atau diarahkan oleh guru [30]. Jadi dalam pembelajaran kooperatif guru lebih bertindak sebagai fasilitator yang menyiapkan tugas dan pertanyaanpertanyaan dan menyediakan bahan-bahan 
yang dirancang guna membantu peserta didik dalam menyelesaikan masalah.

Hasil penelitian menunjukkan bahwa adanya perbedaan hasil belajar kognitif yang diperoleh antara kelas eksperimen model CTL dengan kelas kontrol model examples non examples, yang mana hasil tersebut juga digunakan untuk mengukur kemampuan berpikir kritis dari siswa. Hasil rata-rata nilai yang didapat kelas eksperimen lebih tinggi dibandingkan dengan hasil yang didapatkan oleh kelas kontrol. Tentunya ini juga berarti bahwa kemampuan berpikir kritis dari kelas eksperimen lebih tinggi dari kelas kontrol.

Pada kelas kontrol, ada kemungkinan bahwa daya tangkap siswa cenderung lebih rendah karena pada model pembelajaran examples non examples salah satu kekurangannya adalah membutuhkan waktu yang banyak. Terutama bagi siswa untuk menganalisis dan mendiskusikan gambar-gambar yang diberikan untuk memperoleh konsep yang esensial mengenai materi sistem komputer. Penggunaan waktu yang lama merupakan salah satu kelemahan model examples non examples [31]. Examples non examples adalah model pembelajaran yang membelajarakan murid terhadap permasalahan yang ada di sekitarnya melalui analisis contoh-contoh berupa gambar-gambar, foto, dan kasus yang bermuatan masalah [32]. Dengan seperti itu murid diarahkan untuk untuk mengidentifikasi masalah, mencari alternatif pemecahan masalah, dan menentukan cara pemecahan masalah yang paling efektif, serta melakukan tindak lanjut, dan tentunya hal ini membutuhkan banyak waktu. Sedangkan pada saat penelitian, peneliti hanya memiliki waktu dua jam pelajaran saja dalam satu kali pertemuan. Di samping kekurangan yang dimiliki tersebut, disisi lain model pembelajaran examples non examples tetap memiliki dampak yang baik dalam meningkatkan hasil belajar kognitif dan kemampuan berpikir kritis siswa. Hal ini bisa dilihat dari hasil kemampuan akhir siswa yang meningkat jika dibandingkan dengan kemampuan awal yang dimiliki sebelumnya. Jadi penerapan model examples non examples masih memiliki dampak yang cukup signifikan dalam meningkatkan hasil belajar kognitif dan kemampuan berpikir kritis siswa.

Pada kelas eksperiemen, penerapan model CTL mengajarkan siswa untuk memahami suatu materi yang mereka diskusikan dan pelajari dengan mengkaitkan dengan hal-hal yang terjadi disekitar mereka sesuai dengan materi yang dipelajari dengan dibantu oleh guru. Sehingga disini siswa belajar memahami konsep suatu materi dengan mengkaitkan apa yang sedang mereka pelajari dengan pengalaman mereka sendiri yang pernah dialami atau dijumpai dalam keseharian. Sejalan dengan hal tersebut, CTL menekankan keterlibatan siswa secara penuh untuk dapat menemukan konsep materi dan menghubungkannya dengan situasi kehidupan nyata sehingga mendorong siswa untuk dapat menerapkannya dalam kehidupan seharihari [33]. Alhasil di dalam proses pembelajaran, siswa di kelas eksperimen terlihat lebih banyak yang aktif dan berani dalam bertanya maupun mengemukakan pendapat jika dibandingkan dengan kelas kontrol. Dengan seperti itu siswa akan lebih mudah dalam memahami konsep dari materi yang mereka terima dan pelajari. Hal tersebut memiliki pengaruh yang signifikan terhadap pencapaian hasil belajar kognitif dan kemampuan berpikir kritis siswa pada kelas eksperimen. Karena 
dengan siswa mengkaitkan materi pembelajaran dengan situasi nyata di kehidupan keseharian mereka, membuat proses belajar akan terasa lebih asik dan menyenangkan. Ini sejalan dengan salah satu karakteristik dari pembelajaran dengan model CTL, yaitu pembelajaran dilaksanakan dalam situasi yang menyenangkan [34]. Siswa pun dapat dengan mudah memahami konsep pada suatu materi. Dibuktikan dengan perolehan hasil belajar kognitif dan kemampuan berpikir kritis yang lebih tinggi dibanding perolehan yang didapatkan kelas kontrol.

\section{SIMPULAN}

Perolehan data kelas eksperimen setelah diberi perlakuan model CTL menunjukkan peningkatan terhadap kemampuan berpikir kritis dan hasil belajar kognitif siswa dibandingkan kemampuan awal yang dimiliki sebelumnya. Sebanyak $29 \%$ siswa berkemampuan sangat tinggi, $10 \%$ siswa berkemampuan tinggi, $42 \%$ siswa berkemampuan sedang, $6 \%$ berkemampuan rendah dan $13 \%$ sangat rendah. Hasil belajar kognitif siswa sebelum adanya perlakuan memiliki ratarata sebesar 67,26, sedangkan sesudah adanya perlakuan meningkat sebesar 89,16. Begitu juga perolehan data kelas kontrol setelah diberi perlakuan model Examples Non Examples juga menunjukkan peningkatan terhadap kemampuan berpikir kritis dan hasil belajar kognitif siswa dibandingkan kemampuan awal sebelumnya. Sebanyak $7 \%$ siswa berkemampuan sangat tinggi, 20\% siswa berkemampuan tinggi, $23 \%$ siswa berkemampuan sedang, 20\% berkemampuan rendah dan $30 \%$ sangat rendah. Hasil belajar kognitif siswa sebelum adanya perlakuan memiliki rata- rata sebesar 67,57, sedangkan sesudah adanya perlakuan meningkat sebesar 83,90. Terdapat perbedaan signifikan kemampuan berpikir kritis dan hasil belajar kognitif siswa yang signifikan antara kelas eksperimen model CTL, dengan kelas kontrol model examples non examples. Bisa dilihat dari hasil uji-t dimana nilai signifikansi lebih kecil dari 0,05 $(0,002<$ $0,05)$.

Lembaga dapat mulai menjadikan model pembelajaran CTL dan model pembelajaran examples non examples sebagai model yang dapat diterapkan pada setiap mata pelajaran maupun setiap kelas, untuk membuat pembelajaran lebih efektif dan efisien, sehingga diharapkan terjadi peningkatan kualitas pembelajaran yang dapat menghasilkan hasil belajar kognitif yang optimal sekaligus meningkatkan kemampuan berpikir kritis pada siswa. Serta kedepannya, apabila ada yang ingin melakukan penelitaian serupa, diharapkan untuk dapat lebih memaksimalkan penerapan model CTL dan model Examples Non Examples dengan persiapkan yang lebih matang lagi sesuai dengan kondisi yang ada di sekolah, sehingga diharapkan kekurangan atau kesalahan yang terjadi pada penelitian ini dapat diminimalisir, dan perolehan hasilnya pun akan lebih optimal terutama terkait kemampuan berpikir kritis dan hasil belajar kognitif.

\section{DAFTAR PUSTAKA}

[1] S. N. RI, Undang-undang Republik Indonesia Nomor 20 Tahun 2003 tentang Sistem Pendidikan Nasional. Indonesia, 2003.

[2] M. P. dan K. RI, Lampiran Peraturan Menteri Pendidikan dan Kebudayaan Nomor 20 Tahun 2016 tentang Standar Kompetensi Lulusan Pendidikan Dasar dan Menengah. Indonesia, 2016.

[3] B. Suryosubroto, Proses Belajar Mengajar di Sekolah, Ed. Rev. Jakarta: PT. Rineka Cipta, 2009. 
[4] R. H. Ennis, "The nature of critical thinking: An outline of critical thinking dispositions and abilities. Presentation at the Sixth International Conference on Thinking at MIT, Cambridge, MA, July, 1994,' faculty.education.illinois.edu, 2011.

[5] E. Mulyasa, Kurikulum Berbasis Kompetensi. Bandung: PT Remaja Rosdakarya, 2006.

[6] Trianto, Model-model pembelajaran inovatif berorientasi konstruktivistik. Jakarta: Prestasi Pustaka, 2007.

[7] W. Sanjaya, Strategi pembelajaran. Jakarta: Kencana, 2006.

[8] U. Sumarmo, "Kemampuan Pemahaman dan Penalaran Matematika Siswa SMA dikaitkan dengan Kemampuan Penalaran Logik Siswa dan Beberapa Unsur Proses Belajar Mengajar,' UPI, 1987.

[9] P. Utami, G. P. Cikarge, M. E. Ismail, and S. Hashim, "Teaching Aids in Digital Electronics Practice through Integrating 21st Century Learning Skills using a conceptual approach," in Journal of Physics: Conf. Series, 2018, pp. $1-9$.

[10]B. Trilling and C. Fadel, 21st Century Skills Learning for Life in Our Times. San Fransisco: Jossey-Bass A Wiley Imprint, 2009.

[11]N. A. Djafar, "Penerapan Model Pembelajaran Example Non Example untuk Meningkatkan Kemampuan Berpikir Kritis Peserta Didik Kelas Viii.K SMP Negeri 4 Sungguminasa Kabupaten Gowa," J. Bionature, 2014.

[12]I. G. P. Sudiarta, "Pengembangan Kompetensi Berpikir Divergen dan Kritis Melalui Pemecahan Masalah Matematika OpenEnded," J. Pendidik. dan Kebud., vol. 13, 2007.

[13]Djamarah and Syaiful Bahri, Strategi belajar mengajar, Cet. 3. Jakarta: Rineka Cipta, 2006.

[14]Kunandar, Guru Profesional: Implementasi Kurikulum Tingkat Satuan. Pendidikan (KTSP) dan Sukses dalam Sertifikasi Guru. Raja Grafindo Persada, 2008.

[15] Mahfud, Z. Trio, and Joko, "Pengaruh Metode Pembelajaran Example Non Example Pada Standar Kompetensi Merawat Peralatan Rumah Tangga Listrik Terhadap Hasil Belajar Siswa Di SMK Negeri 1 Cerme Gresik," J. Tek. Elektro, vol. 2, 2013.

[16]M. S. Muhammad, "Implementasi Metode CTL (Contextual Teaching and Learning) Untuk Meningkatkan Hasil Belajar Dan Partisipasi Siswa pada Mata Pelajaran Produktif TKJ Siswa Kelas XI TKJ 4 di SMK Islam 1 Durenan Trenggalek," Universitas Negeri Malang, 2014.

[17] Nurhadi and G. S. Agus, Pembelajaran Kontekstual (Contextual Teaching and Learning/CTL) dan Penerapannya Dalam $K B K$. Malang: Universitas Negeri Malang, 2003.
[18]H. Mifhatul, Model-model Pengajaran Dan Pembelajaran. Yogyakarta Pustaka Pelajar, 2013.

[19]Sugiyono, Metode Penelitian Kuantitatif, Kualitatif dan R\&D. Bandung Alfabeta, 2009.

[20] Arikunto, Suharsimi, Prosedur Penelitian: Suatu Pendekatan Praktik (Edisi Revisi). 2013.

[21]S. Arikunto, Dasar-dasar Evaluasi Pendidikan. Jakarta, 2012.

[22] J. F. . H. Jr, W. C. . Black, B. J. Babin, and R. E. Anderson, Multivariate Data Analysis, Senventh. Edinburgh Gate: Pearson Education Limited, 2010.

[23] A. B. Eisingerich and G. Rubera, "Drivers of Brand Commitment: A Cross-National Investigation," J. Int. Mark., 2010.

[24] S. Uyanto, Pedoman analisis data dengan SPSS, Ed.3. Yogyakarta: Graha Ilmu, 2009.

[25] Purwanto, Evaluasi hasil belajar. Yogyakarta: Pustaka Pelajar, 2013.

[26]W. A. Oktaviansa and Yunus, "Pengaruh Model Pembelajaran CTL (Contextual Teaching and Learning) Terhadap Motivasi dan Hasil Belajar Siswa SMKN 1 Sidoarjo," J. Pendidik. Tek. Mesin, vol. 2, no. 1, 2013.

[27]C. Wijaya,Kemampuan dasar guru dalam proses belajar-mengajar. Bandung: Remaja Rosdakarya, 2010.

[28] Komariah, R. S., Subarjah, Sujana, and dan Herman, "Pengaruh Model Pembelajaran Contextual Teaching And Learning Terhadap Kemampuan Berpikir Kritis Siswa Pada Materi Energi Panas(Penelitian Eksperimen terhadap Siswa Kelas IV SDN Panyingkiran III dan SDN Padasuka I di Kecamatan Sumedang Utara Kabupaten Sum," UPI Kampus Sumedang, 2016.

[29]Rusman, "Model-model Pembelajaran Mengembangkan Profesionalisme Guru," in Jakarta: Rajawali Pers, Rajawali Pers, 2012, p. 418.

[30] A. Suprijono, Cooperative Learning Teori Dan Aplikasi PAIKEM. pustaka pelajar, 2009.

[31]B. Joyce, M. Weil, and E. Calhoun, Models of Teaching (Model-model Pengajaran Edisi Kedelapan). Yogyakarta: pustaka pelajar, 2009.

[32]K. Komalasari, Pembelajaran Kontekstual Konsep dan Aplikasi. 2010.

[33]W. Sanjaya, "Strategi Pembelajaran Berorientasi Standar Proses Pendidikan," System, 2012.

[34]M. Muslich, "Pembelajaran Berbasis Kompetensi Dan Kontekstual," Jakarta PT. Bumi Aksara, 2011. 